\title{
79. BIOSTRATIGRAPHIC SUMMARY, LEG 37, DEEP SEA DRILLING PROJECT
}

\author{
Gregory A. Miles, University of Oregon, Eugene, Oregon \\ and \\ Robert C. Howe, Indiana State University, Terre Haute, Indiana
}

\section{INTRODUCTION}

During Leg 37 of the Deep Sea Drilling Project, four sites were drilled on the west flank of the Mid-Atlantic Ridge at approximately $37^{\circ} \mathrm{N}$. They are situated on a line perpendicular to the spreading axis, with Sites 332 and 333 close together near the Median Valley, and Sites 334 and 335 progressively farther from it. The distances of these sites from the Median Valley are 33.9, $34.3,104.3$, and $181.5 \mathrm{~km}$, respectively.

Sediments recovered during Leg 37 range in age from middle Miocene to Quaternary. The ages of the oldest sediments recovered above acoustic basement are early late Pliocene at Sites 332 and 333, early late Miocene at Site 334, and late middle Miocene at Site 335. These ages closely match the magnetic anomaly ages in all but Site 335 , where a precise magnetic anomaly identification was not possible.

Continuously cored intervals at Leg 37 sites are confined to short upper Pliocene sections near acoustic basement in Holes 332A and 333 and a 13-core upper Miocene section in Hole 334. As a result of discontinuous coring in all other intervals, many zone and epoch boundaries were not recovered, and the determination of stratigraphic position of sediments recovered below lengthy washed intervals was sometimes difficult.

\section{ZONATIONS}

The zonal schemes used in Leg 37 investigations are shown in Figure 1. These have been constructed from microfossil successions in low-latitude areas, and may not be the most favorable for use in the central North Atlantic. However, the overall agreement of sediment age assignments determined by means of the various microfossil groups suggests that the zonations can be applied to the higher latitude sediments from Leg 37 .

The equatorial zonation of Blow (1969) was applied to planktonic foraminiferal faunas with limited success. Difficulties in utilizing this zonal scheme are principally the result of the rarity or absence of many zone taxa due apparently to the mid-latitude position of Leg 37 sites. Zone taxa which are absent from sediments recovered at these sites are Globorotalia merotumida, $G$. plesiotumida, G. tosaensis tenuitheca, Sphaeroidinella dehiscens excavata, and $S$. subdehiscens paenedehiscens. The stratigraphic utility of many N-zone taxa is severely limited by their absence or sporadic occurrences near their respective datum levels. These taxa include Globoquadrina altispira, Globorotalia multicamerata, $G$. tumida, Pulleniatina obliquiloculata, and Sphaeroidinella dehiscens. The tropical Atlantic Pliocene zonation of Berggren (1973) was useful for Pliocene biostratigraphy due to the common occurrence of most of the zone species. The rarity of some of these species, however, precluded the recognition of Zones PL4 and PL6. The absence of the latter zone may be the result of failure to recover this interval during drilling operations.

The stratigraphic positions of Leg 37 samples were determined by using Berggren's Pliocene PL zones and several reliable datum planes in the Miocene. These stratigraphic positions were then correlated to Blow's standard planktonic foraminiferal zonation. Most references to foraminiferal zones in this volume are expressed in terms of Blow's zonation because of its wide use by workers of planktonic foraminifera.

The tropical calcareous nannofossil zonations of Martini (1971b) and Bukry $(1973,1975)$ and the diatom zonations of Burckle (1972), Schrader (1974), and Schrader and Burckle (in press) were used successfully in the biostratigraphy of Leg 37 sediments. No existing zonation could be used in the silicoflagellate biostratigraphy of sediments recovered during Leg 37 . This problem was resolved by the construction of a zonal scheme based on the work of Martini (1971a) and Bukry and Foster (1973), with the addition of a new regional zone, the Dictyocha stapedia stapedia Zone (Bukry, this volume).

\section{SUMMARIES OF MICROFOSSIL INVESTIGATIONS}

\section{Planktonic Foraminifera}

Planktonic foraminiferal faunas were examined by G.A. Miles (Chapter 76, this volume).

Faunas from Hole 332A were examined in six cores above the uppermost occurrence of basalt and in Cores 13 and 22 from within basement. Core 1 is Pleistocene in age, while Cores 2 through 22 are assigned to the Pliocene. The interval from the top of Core 2 through Sample 332A-5-6, 50-52 cm is late Pliocene in age and is placed in that part of Zone N21 which corresponds to Berggren Zones PL4-PL5. This agrees with calcareous nannofossil determinations, but zone assignments based on diatoms place most of this interval in the lower Pliocene. Samples from lowermost Core 5 and from Cores 6 and 13 are placed in Zone N20, based on the common occurrence of Sphaeroidinella seminulina and $S$. subdehiscens, and on the absence of early Pliocene species. Samples from a chalk interbed in Core 22, Section 1, contain rare Globigerina nepenthes and Globorotalia margaritae and are assigned to Zone N19. 


\begin{tabular}{|c|c|c|c|c|c|c|c|c|c|c|c|}
\hline \multirow{3}{*}{ 崖豈 } & \multirow{3}{*}{$\begin{array}{l}\text { 등 } \\
\text { 는 }\end{array}$} & \multirow{3}{*}{ 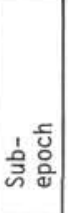 } & \multirow{3}{*}{ 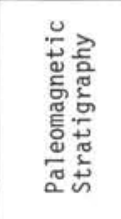 } & \multicolumn{2}{|c|}{$\begin{array}{l}\text { Planktonic } \\
\text { Foraminiferal } \\
\text { Zonation }\end{array}$} & \multicolumn{3}{|c|}{$\begin{array}{l}\text { Calcareous } \\
\text { Nannoplankton } \\
\text { Zonation }\end{array}$} & \multicolumn{2}{|c|}{$\begin{array}{l}\text { Diatom } \\
\text { Zonation }\end{array}$} & $\begin{array}{l}\text { Silico- } \\
\text { flagellate } \\
\text { Zonation }\end{array}$ \\
\hline & & & & \multirow{2}{*}{$\begin{array}{l}\text { Blow } \\
(1969)\end{array}$} & \multirow{2}{*}{$\begin{array}{l}\text { Berggren } \\
(1973)\end{array}$} & \multirow{2}{*}{$\begin{array}{l}\text { Martini } \\
(1971 a)\end{array}$} & \multicolumn{2}{|c|}{ Bukry (1975) } & \multirow{2}{*}{$\begin{array}{c}\text { Burkle (1972) } \\
\text { Schrader and } \\
\text { Burckle (in press) }\end{array}$} & $\begin{array}{c}\text { Schrader } \\
(1974)\end{array}$ & \multirow{2}{*}{$\begin{array}{l}\text { Bukry } \\
\text { (this } \\
\text { volume) }\end{array}$} \\
\hline & & & & & & & Zone & Subzone & & TID Zone & \\
\hline \multirow{5}{*}{ - } & \multirow{5}{*}{ 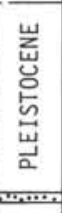 } & \multirow{2}{*}{\begin{tabular}{|l|l|}
\multirow{2}{*}{} & \\
\end{tabular}} & \multirow{2}{*}{ BRUNHES } & \multirow[b]{2}{*}{ N23 } & \multirow[t]{5}{*}{$\mathrm{NN} 21 \rightarrow-$} & NN2O & \multirow{2}{*}{$\begin{array}{l}\text { Emitiania haxieyt } \\
\text { Gephyrocaps } \alpha \\
\text { oceanica }\end{array}$} & \multirow{2}{*}{$\begin{array}{l}\text { Ceratolithes oristatue } \\
\text { Emiliania ovata }\end{array}$} & \multirow{5}{*}{$\begin{array}{c}\text { Pseudoeunotia } \\
\text { doliolus }\end{array}$} & 1 & \multirow{8}{*}{$\begin{array}{c}\text { Dictyocha } \\
\text { aculeata } \\
\text { =ニ=ニ二= } \\
\text { Dictyocha } \\
\text { stapedia } \\
\text { stapedia }\end{array}$} \\
\hline & & & & & & \multirow{3}{*}{ NN19 } & & & & 2 & \\
\hline & & \multirow{3}{*}{$\underset{\omega}{\frac{\pi}{5}}$} & \multirow{5}{*}{$\begin{array}{l}\text { MATUYA- } \\
\text { MA }\end{array}$} & \multirow{3}{*}{ N22 } & & & \multirow{2}{*}{$\begin{array}{l}\text { Crenalithus } \\
\text { doronicoides }\end{array}$} & & & $\frac{3}{4}$ & \\
\hline & & & & & & & & caribbeanica & & 5 & \\
\hline & & & & & & NN18 & & $\begin{array}{l}\text { Smiliania annuta } \\
\text { c. macintyrei }\end{array}$ & & 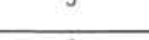 & \\
\hline $2-1$ & & & & & PL6 & NN17 & & $\begin{array}{l}\text { C. macintyrei } \\
\text { - miecuster pentaradiat } \\
\text { inscoaster }\end{array}$ & & 6 & \\
\hline & & 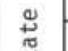 & & N21 & PL5 & & browieri & $\begin{array}{c}\text { Discoaster } \\
\text { surculus }\end{array}$ & $\begin{array}{l}\text { Rhizosolenia } \\
\text { praebergonii }\end{array}$ & 7 & \\
\hline & & $\Xi$ & GAUSS & & PL4 & NN16 & & Discoaster & & 8 & \\
\hline $3-$ & 恺 & & & N20 & $\begin{array}{l}\text { PL4 } \\
P L 3 \\
\end{array}$ & NN15 & & $\frac{\text { tomalis }}{\text { Discoaster }}$ & & 9 & $---?--$ \\
\hline & $\vec{a}$ & & & & PL2 & IIIV & $\begin{array}{l}\text { Retrculofenestra } \\
\text { pseudowbilica }\end{array}$ & $\frac{\text { asymetricus }}{\text { Sphenotithus }}$ & $\begin{array}{l}\text { Mitsachia } \\
\text { jousece }\end{array}$ & $\begin{array}{l}10 \\
11\end{array}$ & \\
\hline $4-1$ & & $\frac{\pi}{2}$ & & N19 & & NN14 & & neoabies & & 12 & \\
\hline & & & GILBER & & PL1 & NN13 & & migosus & & & \\
\hline 57 & $\because \because$ & $\therefore$ & & N18 & & & $\begin{array}{c}\text { Ceratolithus } \\
\text { tricomiculatus }\end{array}$ & $\begin{array}{l}\text { Ceratolithus } \\
\text { acutus }\end{array}$ & & 13 & \\
\hline & & & EPOCH 5 & & & NN12 & & 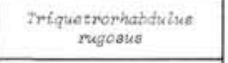 & $\begin{array}{c}\text { Thalassiosina } \\
\text { comvexa }\end{array}$ & 14 & \\
\hline $6-$ & & & & & & & & Ceratolithus & & & \\
\hline & & & EPOCH 6 & & & & $\begin{array}{l}\text { Discoaster } \\
\text { quinqueramus }\end{array}$ & primus & & 15 & \\
\hline & & & & N17 & & & & Diacoaster bergorenti & $\begin{array}{l}\text { Nitzschia } \\
\text { miocenica }\end{array}$ & 16 & \\
\hline $7-$ & & & & & & & & Discoaster & miocenica & 17 & \\
\hline & & & EPOCH 7 & & & & & neorectus & Witzschia & 18 & \\
\hline $8=$ & & 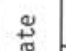 & & & & NN11 & & & porteri & 19 & \\
\hline & & ב & EPOCH 8 & & & & & & & 20 & \\
\hline $10-$ & $\begin{array}{l}\sum_{\breve{U}}^{山} \\
\text { 崖 }\end{array}$ & & EPOCH 9 & N16 & & & $\begin{array}{l}\text { neohamatus } \\
\text { neomatus }\end{array}$ & $\begin{array}{l}\text { Discoaster } \\
\text { betlus }\end{array}$ & $\begin{array}{c}\text { Coscinodiscus } \\
\text { yabei }\end{array}$ & 21 & $\begin{array}{l}\text { Dictyocha } \\
\text { aspera }\end{array}$ \\
\hline 11$]$ & & & EPOCH 10 & N15 & & & & & & $?$ & \\
\hline $12-$ & & & & N14 & & NN9 & & calyculus & & & \\
\hline & & $\stackrel{0}{1}$ & EPOCH II & $\mathrm{N} 13$ & & NN8 & hamatus & & $\begin{array}{l}\text { Cussia } \\
\text { paleacea }\end{array}$ & & \\
\hline & & 華 & & $\mathrm{N} 12$ & N11 & NN7 & & 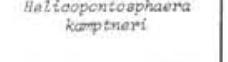 & & & \\
\hline 137 & & & 12 & & $-\begin{aligned} N_{N} 6^{-} \\
\text {N10 }\end{aligned}$ & & Catinaster coalit & Diascaeter kugleri & & & \\
\hline & & & et seq. & N9 & & NN5 & $\begin{array}{l}\text { Discoaster } \\
\text { exilis }\end{array}$ & $\begin{array}{l}\text { Coccolithus } \\
\text { miopelagicus }\end{array}$ & $\begin{array}{l}\text { Denticula } \\
\text { nicobarica }\end{array}$ & & \\
\hline
\end{tabular}

Figure 1. Correlation of paleomagnetic stratigraphy and planktonic foraminiferal, calcareous nannoplankton, diatom, and silicoflagellate zonations used in Leg 37 investigations. With the exception of the diatom zonations, all boundaries are positioned in accordance with the absolute time scale of Berggren and van Couvering (1974). The diatom zone boundaries are positioned in accordance with the absolute time scale of Berggren (1972).

Pliocene sediments from Hole 332B were examined in Core 1 , which was recovered above the uppermost occurrence of basalt, and in Core 6, which is from a calcareous interbed in basement. The latter core is assigned to Zone N20 due to the presence of numerous Sphaeroidinella seminulina and S. subdehiscens. Core 1 , however, contains only rare specimens of these species, and its stratigraphic position is less certain.
Despite the close proximity of Holes $332 \mathrm{~A}$ and 332B and the similar stratigraphic positions occupied by Core 6 of Hole $332 \mathrm{~A}$ and Core 1 of Hole 332B, sediments from the latter core may be slightly younger than those of the former. Planktonic foraminiferal faunas from Core 1 of Hole 332B contain Globorotalia multicamerata and Globoquadrina altispira, but in situ specimens of Globorotalia margaritae are absent. This 
probably limits the range of the core to Berggren Zones PL3 and PL4. If the rare specimens of S. seminulina and $S$. subdehiscens in Core 1 are in situ, the core should be assigned to Berggren Zone PL3, which is approximately equivalent to Zone N20. If they are not in situ, the core probably belongs in Berggren Zone PL4, which is correlative with the lowermost part of Zone N21. The absolute age interval occupied by Zones PL3 and PL4 is 2.8 to 3.3 m.y.B.P. The specimens of $S$. seminulina and $S$. subdehiscens occur within an interval of rare reworked Globorotalia margaritae which includes most of the core. Because of the lack of abrasion or discoloration, it cannot be unequivocally determined if the specimens of $S$. seminulina and $S$. subdehiscens have been reworked.

Foraminifera from Site 333 range in age from late Pliocene to Pleistocene. Cores 2 and 3 of Hole 333 are placed in upper Pliocene Zone N21, based on the presence of Globorotalia miocenica and on the absence of Globorotalia truncatulinoides and definitely in situ $S$. seminulina and $S$. subdehiscens. The first downhole common occurrence of specimens of the last two species is at the top of Core 4, and the Zone N20/N21 boundary is placed in the washed interval between Cores 3 and 4 . Cores 4 through 7 are assigned to Zone N20. With only minor exceptions, these assignments are in agreement with those based on calcareous nannofossils and diatoms.

Foraminifera recovered from Cores 2 through 14 at Site 334 are late Miocene in age. Sediments near the uppermost occurrence of basalt contain Globoquadrina advena and rare Globorotalia acostaensis. The joint occurrence of these species indicates an early late Miocene age. Foraminiferal faunas in Core 20, recovered from a calcareous interbed in basement, are similar to those of Core 14 above basement, and are assigned to the upper part of Zone N15. Calcareous nannofossil floras from Core 20 are also placed near the middle Miocene-late Miocene boundary.

Five cores of sediment recovered above basement at Site 335 range in age from middle Miocene to late Pliocene. Sediment in Core 5 was recovered not more than a few meters above the uppermost occurrence of basalt, and is assigned to Zone N14, based on the cooccurrence of Globorotalia siakensis and Globigerina nepenthes. The presence of numerous specimens of the latter species indicates a maximum absolute age of 12 m.y.B.P. for this core.

\section{Calcareous Nannoplankton}

Age determinations using calcareous nannofossils were made independently by D. Bukry and R.C. Howe (this volume). Most ages are in nearly complete agreement. Some differences probably have resulted from Howe's use of the standard zonation of Martini (1971b) aboard ship, whereas Bukry has used his own zonation (Bukry, 1973; 1975). Onshore, Howe attempted to use Bukry's zonal scheme. These later results still in some cases differ slightly from those of Bukry.

Bukry assigns Hole 332A sediments from immediately above basement to his upper Pliocene Discoaster tamalis Subzone, which has an age of 2.5 to 3.0 m.y.B.P. (Bukry, 1975). Although Sphenolithus abies is absent from his samples, Howe places sediments below Section 5, Core 5, Hole 332A in Bukry's older $D$. asymmetricus Subzone (3.0 to 3.5 m.y.B.P.), based on the presence of a few large specimens of Reticulofenestra pseudoumbilica in his samples. Howe also found small $R$. pseudoumbilica in samples as high as Section 4 of Core 3 . If these specimens are correctly identified, these results support Ellis's (1975) conclusion that the $D$. tamalis/D. asymmetricus Subzone boundary of Bukry is slightly older than the Zone NN15/NN16 boundary of Martini (1971b).

Both Bukry and Howe conclude that sediments above basement from Hole $332 \mathrm{~B}$ belong to the $D$. tamalis Subzone and those from Hole 333 belong to the $D$. asymmetricus Subzone. However, for the same reasons stated above, Bukry's D. tamalis $/ D$. asymmetricus Subzone boundary in Hole 333 is placed lower (between Sections 1 and 2, Core 7) than is Howe's (between Sections 3 and 4, Core 3).

Sediments near basement from Site 334 are assigned to the Discoaster bellus Subzone by Bukry and Howe, giving them an early late Miocene age of 7.3 to 11.0 m.y.B.P. (Bukry, 1975). Samples recovered a few meters above basement in Core 5 of Site 335 are placed in the Discoaster kugleri Subzone by Bukry and tentatively by Howe, giving those sediments a middle Miocene age of 13.0 to 14.0 m.y.B.P. (Bukry, this volume).

Several age determinations were made for Holes $332 \mathrm{~A}, 332 \mathrm{~B}$, and Site 334 chalk samples recovered from layers interstratified with basalts in basement. In each case, Howe has assigned ages which are similar to those of the sediments just above the upper basement contact. Samples from Cores 13, 22, and 25, Hole 332A, and from Core 6, Hole 332B, are placed in the $D$. asymmetricus Subzone. Bukry has assigned a sample from Core 20, Site 334, to his Catinaster calyculus Subzone. Howe tentatively assigned a similar sample to the younger $D$. bellus Subzone, since he did not identify the guide species Discoaster hamatus indicative of the older subzone. An unusual nannofossil sample from the calcareous matrix of a breccia in Core 22 of Site 334 has been assigned a late middle Miocene age by Bukry.

\section{Diatoms}

Diatom floras from Leg 37 were examined by H.-J. Schrader (this volume).

At Site 332, samples from Hole 332 are barren, but the majority of those from Holes $332 \mathrm{~A}$ and 332B contain diverse tropical diatom assemblages. Core 1 and uppermost Core 2 of Hole $332 \mathrm{~A}$ are assigned to the Nitzschia jouseae Partial Range Zone of Burckle (1972), based on the co-occurrence of $N$. jouseae and Thalassiosira convexa. This zone extends through the mid-Pliocene and occupies an absolute age interval of approximately 2.8 to $4.3 \mathrm{~m}$.y.B.P. The mid-Pliocene age assignment of Core 1 is significantly older than its Quaternary assignment based on calcareous nannofossils and planktonic foraminifera. The remainder of Core 2, and Cores 3, 4, and 5 are placed in the lower Pliocene Thalassiosira convexa Partial Range Zone of Burckle (1972). Samples below 332A-5-5, 58-60 cm are 
barren. Five samples from Hole 332B are assigned to the upper Pliocene Rhizosolenia praebergonii Partial Range Zone of Burckle (1972).

Diverse tropical diatom assemblages of Pliocene age are present in Cores 2 through 5 and in the upper part of Core 6 in Hole 333. Sediments from Section 1 of Core 2 through Section 4 of Core 4 are assigned to the upper Pliocene Rhizosolenia praebergonii Partial Range Zone and occupy an absolute age interval of approximately 2.1 to 2.8 m.y.B.P. Sediments beneath this interval to Section 1 of Core 6 are placed in the midPliocene Nitzschia jouseae Partial Range Zone.

Diatom assemblages at Site 334 which contain agediagnostic taxa are present only in Cores 4 through 13 . The interval from Section 1 of Core 4 to Section 1 of Core 7 contains Nitzschia cylindricus, $N$. fossilis, $N$. marina, $N$. porteri, and $N$. praereinholdii, and is placed in the upper part of the Nitzschia porteri Partial Range Zone of Burckle (1972). The sediments beneath this interval through Section 1 of Core 8 are placed in the lower part of this zone. Sediments below Core 8 , Section 1, are assigned to the Coscinodiscus yabei Partial Range Zone of Burckle (1972), based on the last occurrence of members of the Coscinodiscus plicatus group in Sample 334-8-2, 110-112 cm.

Diatoms at Site 335 sufficiently preserved to be used for biostratigraphic purposes are found only in Cores 1 and 5. Core 1 is assigned to the Pseudoeunotia doliolus Range Zone of Burckle (1972), which is Pleistocene in age. On the bases of calcareous nannofossils and planktonic foraminifera, however, this core is assigned to the late Pliocene. Sediments in Core 5 are placed in the middle Miocene Cussia paleacea Partial Range Zone of Schrader and Burckle (in press). This zone is assigned an absolute age of approximately 11.4 to 13.0 m.y.B.P. Similar floras from DSDP Site 238 in the Indian Ocean have been correlated to Blow's (1969) planktonic foraminiferal Zones N14-N15 by Vincent (1974).

\section{Silicoflagellates}

Bukry (this volume) examined 80 samples for silicoflagellates. Two new subspecies, Dictyocha perlaevis ornata Bukry and Distephanus polyactis crassis Bukry, are described and a new regional zone, the Dictyocha stapedia stapedia Zone, is designated in this volume.

Silicoflagellates are absent or rare in most samples from Holes 332A, 332B, 333, and Site 335. Most samples in the upper Pliocene-lower Quaternary interval contain no key stratigraphic marker species, precluding their placement in preexisting zones. Consequently, a new regional zone, the Dictyocha stapedia stapedia Zone, has been proposed as the interval between the first $D$. stapedia stapedia and the first Quaternary Mesocena elliptica. At Site 334, silicoflagellates are numerous in most cores. Core 1 is assigned to the Dictyocha aculeata Zone of late Quaternary age, while Cores 4 through 12 are placed in the upper Miocene Dictyocha aspera Zone.

\section{FOSSIL PRESERVATION}

Calcareous microfossils recovered above basement are well preserved and show few signs of solution. The virtual absence of solution effects appears to be the result of deposition well above the carbonate compensation depth along the Mid-Atlantic Ridge. With the exception of some corroded specimens in Core 5, Site 335 , planktonic foraminifera show no signs of solution. High frequencies of the calcareous nannofossil genera Discolithina and Scyphosphaera indicate minimal solution of nannofossil floras (Roth and Berger, 1975; Bukry, this volume).

Within basement, calcareous fossil preservation is closely tied to sediment induration. Slightly indurated chalk interbeds usually contain well-preserved microfossils, while highly indurated sediment, much of which has been completely recrystallized, is typically barren of calcareous fossils or bears only poorly preserved specimens.

Diatoms, silicoflagellates, and Radiolaria are absent from all sediments recovered from basement, although these siliceous microfossils are common and well preserved in most samples collected above basement. Sediment intervals in which these fossils are absent or only poorly represented may have developed at times when silica undersaturation in these horizons was significant (Berger, 1968).

\section{PALEOCLIMATOLOGY}

Paleoclimatic inferences for the region of Leg 37 sites are derived here from planktonic foraminifera, diatoms, and silicoflagellates. Interpretations from these three groups agree for the Miocene, but differ in some respects for the Pliocene and Pleistocene.

Middle and late Miocene microfossils recovered from Sites 334 and 335 are indicative of warm water conditions. Planktonic foraminiferal faunas include Candeina nitida and numerous specimens of Globigerinoides sacculifer, Globorotalia cultrata, Sphaeroidinella seminulina, and $S$. subdehiscens. Calcareous nannoplankton and diatom floras contain many tropical species, and, with the exception of sediments in Core 5, Dictyocha/Distephanus ratios in silicoflagellate assemblages from the upper Miocene of Site 334 indicate warm conditions throughout the late Miocene.

Pliocene planktonic foraminiferal faunas suggest warm conditions, but with much temperate influence, particularly in the late Pliocene. Many tropical indices, such as Candeina nitida, Globigerinoides fistulosus, Globorotalia cultrata, G. multicamerata, G. tumida, and Pulleniatina spp. are absent or rare in upper Pliocene sediments. Diatom floras, on the other hand, suggest that tropical conditions prevailed throughout the Pliocene, and with the exception of one sample from Hole 332B, silicoflagellates indicate warm conditions during the late Pliocene.

Pleistocene foraminiferal faunas are distinctly temperate in character with minor cold water and warm water influence. These faunas are dominated by Globigerina bulloides, G. falconensis, G. quinqueloba, Globigerinita glutinata, Globorotalia inflata, G. scitula, G. truncatulinoides, and Orbulina universa. Diatom floras from the same Pleistocene intervals at Sites 332, 333, and 334 , as well as silicoflagellate assemblages from Site 334 indicate warm water conditions. 
Planktonic foraminifera from Leg 37 sediments suggest a cooling trend during the middle and late Neogene in the central North Atlantic. Silicoflagellate and diatom assemblages, on the other hand, retain a warm to tropical aspect throughout the same interval of time. These differences in interpretation may be due to the disparate attention various groups have received in the literature. Planktonic foraminifera have been extensively catalogued with respect to latitude and temperature, but much of the recent diatom and silicoflagellate paleoecology is yet unrefined. In view of this, our bias is to accept the middle MiocenePleistocene cooling trend suggested by foraminiferal faunas.

\section{MIXED MICROFOSSIL ASSEMBLAGES}

Downhole contamination resulting from drilling operations was reported only from planktonic foraminiferal assemblages. In many foraminiferal samples, specimens of Quaternary age are mixed with Miocene or Pliocene foraminifera. These Quaternary contaminants are easily recognized because of their exceptional preservation in comparison to in situ faunas. Downhole mixing is most common in Cores 3,4 , and 5 of Hole 332A and in the upper part of Core 7, Site 334, but it is also evident in a small number of other Leg 37 cores.

Displaced older diatoms and calcareous nannofossils were reported only from Hole 333, where reworked diatoms are present in Sample 333-5-2, 70-72 cm and reworked fossils of both groups are present in Core 2. Reworked planktonic foraminifera occur principally in the upper Pliocene sediments of Holes 332A, 332B, and 333 . The most readily recognized contaminant in these sediments is Globorotalia margaritae. This species normally ranges from the upper Miocene to the top of the lower Pliocene. Abraded and discolored scattered specimens of G. margaritae occur in Cores 2, 3, and 5 of Hole $332 \mathrm{~A}$, Core 1 of Hole 332B, and Cores 2 through 7 of Hole 333. A few specimens from Hole 333 show no signs of reworking, and it is possible that they are in situ. However, most samples in which they are present bear other abraded or discolored specimens, and it is likely that all of the G. margaritae in this hole are reworked.

\section{COMPARISON OF PALEOMAGNETIC STRATIGRAPHY AND PALEONTOLOGY}

Hall and Ryall (this volume) have studied the paleomagnetism of 90 sediment samples from Leg 37 holes. Only at Site 334, which was continuously cored from 130 meters subbottom to basement at 259 meters subbottom, is there sufficient section to match the paleomagnetic time scale of Foster and Opdyke (1970), as modified by Berggren and van Couvering (1974).

A comparison of paleontological results based on investigations by Howe (this volume) and Miles (this volume) with the magnetic stratigraphy determined by Hall and Ryall for Site 334 is shown in Figure 2. This correlation is slightly different than that presented in Berggren and van Couvering (1974). If the magnetic and paleontological data have been correctly interpreted, then either the paleomagnetic epoch boundaries must be relatively younger or the biostratigraphic zone boundaries must be older than shown by Berggren and van Couvering (1974). Additional samples have been taken in order to refine the magnetic boundaries, and a revised paleomagnetic profile is forthcoming.

\section{BASEMENT AGES}

\section{Comparison of Fission Track, Paleomagnetic, and Paleontological Ages}

In Table 1, basement ages determined by fission track and paleomagnetic dating are compared to paleontological ages of the oldest datable sediment recovered above basement.

Paleontological and paleomagnetic ages agree well, due to the proximity of the youngest basalts and the oldest recovered Layer 1 sediments in Leg 37 holes. The paleontological ages are slightly younger than those determined from paleomagnetism except at Site 334, where the average microfossil age is approximately 1 m.y. older than the reported age of the magnetic anomaly (anomaly 5) upon which this site is located.

\begin{tabular}{|c|c|c|c|c|}
\hline CORE & POLARITY & $\begin{array}{l}\text { POSSIBLE } \\
\text { EPOCH }\end{array}$ & $\begin{array}{l}\text { PLANK } \\
\text { FORAM }\end{array}$ & $\begin{array}{l}\text { CALCAR } \\
\text { NANNOS }\end{array}$ \\
\hline 2 & & \multirow[b]{3}{*}{$2-$} & \multirow{5}{*}{ N17 } & \multirow{8}{*}{ NN II } \\
\hline 3 & & & & \\
\hline 4 & N & & & \\
\hline 5 & NO & \multirow{3}{*}{9} & & \\
\hline 6 & $\begin{array}{c}N \\
N \\
\text { NODATA }\end{array}$ & & & \\
\hline 7 & $\stackrel{1}{N}$ & & \multirow{6}{*}{ N 16} & \\
\hline 8 & NO DATA & \multirow{7}{*}{10} & & \\
\hline 9 & Rे & & & \\
\hline 10 & NO DATA & & & \multirow{5}{*}{ NN 10} \\
\hline 11 & $\hat{N}$ & & & \\
\hline 12 & \begin{tabular}{|l} 
NO DATA \\
N \\
NO DATA \\
\end{tabular} & & & \\
\hline 13 & $\begin{array}{c}N \\
R\end{array}$ & & \multirow[b]{2}{*}{ N 15} & \\
\hline 14 & NO D্ंATA & & & \\
\hline
\end{tabular}

Figure 2. Possible correlation of paleomagnetic stratigraphy to planktonic foraminiferal and calcareous nannoplankton zones, Site 334. See text for further explanation. $(N=$ normal polarity; $R=$ reverse polarity; ? = indeterminate polarity.) 
Fission track ages from Holes 332A, 332B, and Site 335 are consistently older than average paleontological ages. Planktonic foraminiferal samples recovered from calcareous interbeds in basement in Hole 332A were in proximity to fission track samples and yield similar ages, suggesting that the fission track samples are older as a result of greater depth of sample recovery. In Hole $332 \mathrm{~A}$, foraminiferal samples from Core 22 yield an age of 3.7 to 4.6 m.y.B.P., while fission track ages from Cores 18 and 26 are $3.67 \pm 0.52$ m.y. and $3.65 \pm 0.88$ m.y., respectively (Mitchell and Aumento, this volume). In Hole 332B, foraminifera from Core 6 are assigned an age of 3.0 to 3.3 m.y., while fission track dating yields an age of $3.68 \pm 1.18 \mathrm{~m} . \mathrm{y}$. for a sample from Core 16. This disparity is not unreasonable, considering the difference in depth between the samples. At Site 335 , three fission track samples from Cores 6, 7, and 10 yield an average age of $14.45 \pm 2.27$ m.y. No paleontological ages are available from basement in this hole, but fossil age assignments from sediments a few meters above basement in Core 5 range from 11.4 to $14.0 \mathrm{~m} . \mathrm{y}$. The average paleontological age of sediments in this core is approximately $2 \mathrm{~m}$.y. less than the fission track dates from basement, despite the close proximity of the samples.

\section{Basement Ages Based on Paleontological Determinations}

The extrapolation of basement ages from paleontological age estimates of the oldest sediment recovered above basement is discussed by van Andel and Bukry (1973). The calculation of basement ages proposed by these workers is used here to arrive at a single paleontological age, and limits of error, for the uppermost occurrence of basement at each Leg 37 site.

Basement ages which have been determined biostratigraphically for Leg 37 sites are shown in Table 2 . The biostratigraphic zones on which basement ages are based, and their absolute age limits, are shown in Table 3.

van Andel and Bukry (1973) discuss the use of minimum-overlap and maximum-overlap methods for obtaining the paleontological age of basement from two or more age determinations. The latter method uses the interval from the oldest age determination to the youngest, while the former employs a smaller time interval from the minimum amount of overlap in all the age assignments. van Andel and Bukry conclude that maximum-overlap is less desirable because broad zones or extreme age determinations can greatly influence the resulting basement age. The minimum-overlap technique was employed in the present work, but minor changes in the method had to be made for Sites 332, 334 , and 335 , where age assignments from some microfossil groups do not overlap. At each of these sites, an interval which agrees at least partially with all age determinations has been chosen. For example, ages of the oldest sediment recovered above basement at Site 335 are 11.5 to 12.0 m.y., 13.0 to 14.0 m.y., 12.3 to 12.9 m.y., and 11.4 to 13.0 m.y.B.P., based on planktonic foraminifera, calcareous nannoplankton (two determinations), and diatoms, respectively. Since there is no single minimum-overlap value, the interval of 12.0 to 13.0 m.y.B.P. is chosen for the basement age calculation. This resultant age interval is acceptable in view of the above four age estimates.

Several sources of error are involved in determining absolute basement ages from microfossils in sediments above basement. These include uncertainties in the absolute time scale, in the absolute ages of stratigraphic boundaries, and in the positions of samples within their zones. There may also be a coring error, which represents the difference in time between the formation of the uppermost part of basement and the deposition of the oldest datable sediments recovered above basement. The reader is referred to van Andel (1972) and van Andel and Bukry (1973) for expanded discussions concerning these sources of error.

\section{ACKNOWLEDGMENTS}

We wish to thank J.M. Hall, F. Aumento, D. Bukry, W.S. Mitchell, P.J.C. Ryall, and H.-J. Schrader, whose data were used in this report. Special thanks are given to David

TABLE 1

Basement Ages Derived From Fission Track and Paleomagnetic Dating Compared to Microfossil Ages of the Oldest Sediments Recovered Above Basement

\begin{tabular}{lcccccc}
\hline \multicolumn{1}{c}{ Source } & Hole 332A & Hole 332B & Hole 333 & Hole 333A & Site 334 & Site 335 \\
\hline $\begin{array}{l}\text { Calcareous Nannoplankton } \\
\text { (Bukry, this volume) }\end{array}$ & $2.5-3.0$ & $2.5-3.0$ & $3.0-3.5$ & $2.5-3.0$ & $7.5-11.0$ & $13.0-14.0$ \\
$\begin{array}{l}\text { Calcareous Nannoplankton } \\
\text { (Howe, this volume) }\end{array}$ & $3.0-3.6$ & $3.0-3.6$ & $3.0-3.6$ & $3.0-3.6$ & $10.0-11.0$ & $12.3-12.9$ \\
$\begin{array}{l}\text { Diatoms (Schrader, } \\
\text { this volume) }\end{array}$ & $3.3-4.3$ & $2.1-2.9$ & $2.8-4.3$ & - & $8.2-9.0$ & $11.4-13.0$ \\
$\begin{array}{l}\text { Planktonic Foraminifera } \\
\text { (Miles, this volume) }\end{array}$ & $3.0-3.3$ & $2.8-3.3$ & $3.0-3.3$ & $3.0-3.3$ & $10.5-11.0$ & $11.5-12.0$ \\
$\begin{array}{l}\text { Fission Track (Mitchell } \\
\text { and Aumento, this volume) }\end{array}$ & $3.67 \pm 0.40$ & $3.67 \pm 0.40$ & - & - & - & $14.45 \pm 2.27$ \\
$\begin{array}{l}\text { Paleomagnetic (Hall } \\
\text { and Ryall, this volume) }\end{array}$ & $3.5 \pm 0.1$ & $3.5 \pm 0.1$ & 3.5 & 3.5 & 9.0 & $11.0-16.0$ \\
\hline
\end{tabular}

Note: Precise magnetic-anomaly identification is not possible at Site 335 , and the paleomagnetic age of basement at this site has been extrapolated from spreading rates at Sites 332, 333, and 334. Calcareous nannoplankton and planktonic foraminiferal ages are based on the absolute time scale of Berggren and van Couvering (1974). Diatom ages are based on Berggren (1972). All ages are expressed in millions of years. 
TABLE 2

Basement Ages at Leg 37 Sites

\begin{tabular}{lccccc}
\hline Site & $\begin{array}{c}\text { Distance } \\
\text { from Axis } \\
(\mathrm{km})\end{array}$ & $\begin{array}{c}\mathrm{Age}^{\mathrm{a}} \\
(\mathrm{m} . \mathrm{y} .)\end{array}$ & $\begin{array}{c}\text { Biostrati- } \\
\text { graphic Error } \\
(\mathrm{m} . \mathrm{y} .)\end{array}$ & $\begin{array}{c}\text { Coring } \\
\text { Error } \\
(\mathrm{m} . \mathrm{y} .)\end{array}$ & $\begin{array}{c}\text { Total Age } \\
\text { Error } \\
(\mathrm{m} . \mathrm{y} .)\end{array}$ \\
\hline $332^{\mathrm{b}}$ & 33.9 & 3.2 & \pm 0.6 & None & \pm 0.6 \\
$333^{\mathrm{c}}$ & 34.3 & 3.2 & \pm 0.6 & None & \pm 0.6 \\
334 & 104.3 & 9.8 & \pm 1.8 & +0.2 & $+2.0 /-1.8$ \\
335 & 181.5 & 12.5 & \pm 1.7 & +0.1 & $+1.8 /-1.7$ \\
\hline
\end{tabular}

${ }^{a}$ Ages have been calculated using a modification of the minimumoverlap method of van Andel and Bukry (1973). See text for further explanation.

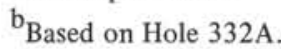

Based on Hole 333.

Bukry, La Jolla Marine Geology Laboratory, U.S. Geological Survey, for contributing information and manuscript suggestions, and to William N. Orr, Department of Geology, University of Oregon, for critically reviewing the manuscript.

\section{REFERENCES}

Berger, W.H., 1968. Radiolarian skeletons: solution at depths: Science, v. 159 , no. 1237.

Berggren, W.A., 1972. A Cenozoic time-scale-some implications for regional geology and paleobiogeography: Lethaia, v. 5 , p. 195.

1973. The Pliocene time-scale: calibration of planktonic foraminiferal and calcareous nannoplankton zones: Nature, v. 243, p. 391.

Berggren, W.A. and van Couvering, J.A., 1974. The late Neogene: biostratigraphy, geochronology and paleoclimatology of the last 15 million years in marine and continental sequences: Amsterdam, Oxford, and New York (Elsevier).

Blow, W.H., 1969. Late middle Eocene to Recent planktonic foraminiferal biostratigraphy: First Intern. Conf. Plank. Microfoss., Proc., v. 1, Leiden (E.J. Brill), p. 199.

Bukry, D., 1973. Low-latitude coccolith biostratigraphic zonation. In Edgar, N.T., Saunders, J.B., et al., Initial Reports of the Deep Sea Drilling Project, Volume 15: Washington (U.S. Government Printing Office), p. 685. 1975. Coccolith and silicoflagellate stratigraphy, northwestern Pacific Ocean, Deep Sea Drilling Project Leg 32. In Larson, R.L., Moberly, R., et al., Initial Reports of the Deep Sea Drilling Project, Volume 32: Washington (U.S. Government Printing Office), p. 677.
Bukry, D. and Foster, J.H., 1973. Silicoflagellate and diatom stratigraphy, Leg 16, Deep Sea Drilling Project. In van Andel, T.H., Heath, G.R., et al., Initial Reports of the Deep Sea Drilling Project, Volume 16: Washington (U.S. Government Printing Office), p. 815.

Burckle, L.H., 1972. Late Cenozoic planktonic diatom zones from the eastern equatorial Pacific: Nova Hedwig., Beihft., v. 39, p. 217.

Ellis, C.H., 1975. Calcareous nannofossil biostratigraphy-Leg 31, Deep Sea Drilling Project. In Karig, D.E., Ingle, J.C., et al., Initial Reports of the Deep Sea Drilling Project, Volume 31: Washington (U.S. Government Printing Office), p. 655.

Foster, J.H. and Opdyke, N.D., 1970. Upper Miocene to Recent magnetic stratigraphy in deep-sea sediments: J. Geophys. Res., v. 75, p. 4465.

Martini, E., 1971a. Neogene silicoflagellates from the equatorial Pacific. In Winterer, E.L., Riedel, W.R., et al., Initial Reports of the Deep Sea Drilling Project, Volume 7: Washington (U.S. Government Printing Office), p. 1695.

- 1971b. Standard Tertiary and Quaternary calcareous nannoplankton zonation: Second Intern. Conf. Plank. Microfoss., Proc., v. 2, p. 739.

Roth, P.H. and Berger, W.H., 1975. Distribution and dissolution of coccoliths in the south and central Pacific: Cushman Found. Foram. Res. Spec. Publ. 13, p. 87.

Schrader, H.-J., 1974. Cenozoic marine planktonic diatom biostratigraphy of the tropical Indian Ocean. In Fisher, R.L., Bunce, E.T., et al., Initial Reports of the Deep Sea Drilling Project, Volume 24: Washington (U.S. Government Printing Office), p. 887.

Schrader, H.-J., and Burckle, L.H., in press. Marine diatom biostratigraphy, its correlation to other microfossil zonations and to the paleomagnetic record. In Riedel, W. R. and Saito, T. (Eds.), Symposium of marine plankton and sediments: New York (Micropaleontology Press).

van Andel, Tj.H., 1972. Establishing the age of the oceanic basement: Comments on earth sci.: Geophysics, v. 2, p. 159.

van Andel, Tj.H. and Bukry, D., 1973. Basement ages and basement depths in the eastern equatorial Pacific from Deep Sea Drilling Project Legs 5, 8, 9, and 16: Geol. Soc. Am. Bull., v. 84, p. 2361.

Vincent, E., 1974. Cenozoic planktonic biostratigraphy and paleooceanography of the tropical western Indian Ocean. In Fisher, R.L., Bunce, E.T., et al., Initial Reports of the Deep Sea Drilling Project, Volume 24: Washington (U.S. Government Printing Office), p. 1111.

TABLE 3

Biostratigraphic Zones on Which Basement Ages of Table 2 are Based and Their Absolute Ages

\begin{tabular}{|c|c|c|c|c|c|c|c|c|}
\hline Site & $\begin{array}{c}\text { Foraminiferal } \\
\text { Zone }^{\mathrm{a}}\end{array}$ & $\underset{(\mathrm{m} . \mathrm{y} .)^{\mathrm{a}}}{\text { Age Limits }}$ & $\begin{array}{c}\text { Nannofossil } \\
\text { Zone/Subzone }^{b}\end{array}$ & $\underset{(\mathrm{m} . \mathrm{y} .)^{\mathrm{b}}}{\text { Age Limits }}$ & $\begin{array}{l}\text { Nannofossil } \\
\text { Zone }^{\mathrm{c}}\end{array}$ & $\begin{array}{l}\text { Age Limits } \\
(\mathrm{m} . \mathrm{y} .)^{\mathrm{c}}\end{array}$ & $\begin{array}{l}\text { Diatom } \\
\text { Zone }^{\mathrm{d}}\end{array}$ & $\begin{array}{l}\text { Age Limits } \\
\text { (m.y. })^{\mathrm{d}}\end{array}$ \\
\hline $332^{\mathrm{e}}$ & $\mathrm{N} 20$ & $3.0-3.3$ & $\begin{array}{l}\text { D. brouweri/ } \\
\text { D. tamalis }\end{array}$ & $2.5-3.0$ & NN15 & $3.0-3.6$ & & $3.3-4.3$ \\
\hline 333 & $\mathrm{~N} 20$ & $3.0-3.3$ & $\begin{array}{l}\text { R. pseudoumbilical } \\
\text { D. asymmetricus }\end{array}$ & $3.0-3.5$ & NN15 & $3.0-3.6$ & N. jouseae & $2.8-4.3$ \\
\hline 334 & Upper N15 & $10.5-11.0$ & $\begin{array}{l}\text { D. neohamatus/ } \\
\text { D. bellus }\end{array}$ & $7.5-11.0$ & NN10 & $10.0-11.0$ & Upper C. yabei & $8.2-9.0$ \\
\hline 335 & N14 & $11.5-12.0$ & D. exilis/D. kugleri & $13.0-14.0$ & NN7 & $12.3-12.9$ & C. paleacea & $11.4-13.0$ \\
\hline
\end{tabular}

${ }^{\mathrm{a}}$ Foraminiferal zones from Blow (1969); age limits from Berggren and van Couvering (1974).

${ }^{b}$ Results of D. Bukry; nannofossil zones from Bukry (1975); age limits from Bukry (this volume) and Berggren and van Couvering (1974).

${ }^{c}$ Results of R. Howe; nannofossil zones from Martini (1971a); age limits from Berggren and van Couvering (1974).

${ }^{\mathrm{d}}$ Diatom zones from Burckle (1972) and Schrader and Burckle (in press); age limits from Schrader (1974) and Berggren (1972).

${ }^{\mathrm{e}}$ Based on Hole 332A.

fBased on Hole 333. 